\title{
Quantitative Strategic Planning Matrix Pemasaran Air Minum dalam Kemasan
}

\author{
Nuraida Wahyuni*1, Daenulhay Kamsin ${ }^{2}$, Evi Febianti ${ }^{3}$, dan Gusti Imam Bimantara ${ }^{4}$ \\ 1,3,4 Jurusan Teknik Industri, Fakultas Teknik, Universitas Sultan Ageng Tirtayasa, \\ Jl. Jend. Sudirman KM 3, Cilegon, 42435, Indonesia \\ ${ }^{2}$ Magister Manajemen, Pascasarjana, Universitas Sultan Ageng Tirtayasa, \\ Jl. Raya Jakarta KM 4, Serang, 42124, Indonesia
}

Email: nrdwahyuni@gmail.com ${ }^{1}$, daenulhaykamsin@gmail.com², evi@untirta.ac.id ${ }^{3}$,imamgusti05@gmail.com ${ }^{4}$

\section{DOI: 10.20961/performa.19.1.40996}

\begin{abstract}
Abstrak
Besarnya permintaan AMDK di Indonesia, mendorong produksi air minum dalam kemasan yang beraneka ragam. Selain merek yang sudah terbiasa ditemui oleh masyarakat, di beberapa daerah mempunyai produk air minum dalam kemasan sendiri, seperti produk air minum Baros, yang terdapat di Serang, Banten. Permasalahan yang terjadi saat ini adalah adanya penurunan penjualan pada produk Baros karena keberadaannya belum dapat menyaingi produk kompetior. Agar dapat bersaing dengan para kompetitor, produk Baros harus menetapkan suatu strategi pemasaran. Tujuan dari penelitian ini adalah menentukan strategi pemasaran yang tepat. Metode yang digunakan adalah QSPM. Hasil penelitian didapatkan bahwa dari kombinasi 6 kesempatan, 6 ancaman, 10 kekuatan dan 5 kelemahan, didapatkan 5 strategi taktis. Dari kelima strategi taktis tersebut kemudian dipilih satu strategi yang paling tinggi nilai TAS-nya. Nilai TAS paling tinggi sebesar 6,26 ada pada strategi kedua yaitu meningkatkan akses penjualan melalui aplikasi media sosial dan online shop yang dapat dipilih menjadi strategi pemasaran produk Baros.
\end{abstract}

Kata kunci: Strategi pemasaran, AMDK, QSPM

\section{Abstract}

Baros is a brand for bottle drinking water products, which are located in Serang, Banten. The problem that occured was a decline in sales of Baros because their existence had not been able to compete with competitor's products. In order to compete with competitors, Baros must establish a marketing strategy. The purpose of this research is to determine the right marketing strategy. The method used was QSPM. The result found that from a combination of 6 opportunities, 6 threats, 10 strengths and 5 weaknesses, obtained 5 tactical strategies. From the five tactical strategies, the one with the highest TAS value was selected. The highest TAS value was 6,26 is in the second strategy, it is: increasing sales through social media and online shops, which can be chosen as a new Baros' marketing strategy.

Keywords: Marketing strategy, bottle drinking water, QSPM

\section{Pendahuluan}

Produk air minum dalam kemasan sudah menjadi bagian dari gaya hidup masyarakat di Indonesia karena praktis. Rini (2018) menyebutkan industri air minum dalam kemasan memiliki permintaan yang kuat. Sepanjang tahun 2017 permintaan air minum dalam kemasan dalam setahun mencapai 27 miliar liter air. Tren di Indonesia biasanya terus meningkat karena adanya momen khusus seperti bulan Ramadan, hari lebaran, hari natal, dan tahun baru, kenaikan diperkirakan 9\% sampai 10\% (Rini, 2018).

Produk air minum dalam kemasan yang beredar selama ini adalah merek-merek dari producen besar yang mudah ditemui di mana saja di seluruh Indonesia. Beberapa daerah di Indonesia mempunyai merek sendiri perihal air minum dalam kemasan. Contohnya di daerah Serang, Banten, yang memiliki produk air minum dalam kemasan dengan merek Baros. Permasalahan yang terjadi saat penelitian dilakukan (pertengahan tahun 2018) adalah dalam beberapa bulan terakhir penjualan AMDK (air minum dalam kemasan) mengalami penurunan khususnya kemasan $600 \mathrm{ml}$. Hal ini disebabkan keberadaan merek ini untuk saat ini belum dapat menyaingi kompetitor. Oleh karena itu, dibutuhkan suatu analisis strategi pemasaran untuk meningkatkan posisi produk lebih maju lagi di antara kompetitor yang ada.

Menurut Tjiptono (2008) sebuah perusahaan dapat bertahan atau dapat mengalami kemajuan di antara kompetitor adalah dengan membuat strategi pemasaran yang dapat mendorong penguatan pangsa pasar sehingga dapat memenuhi permintaan pasar dan tercapainya tujuan perusahaan. Strategi pemasaran merupakan rencana yang menjabarkan dampak dari program pemasaran terhadap permintaan produk pada pasar sasaran

\footnotetext{
${ }^{*}$ Penulis utama (Corresponding author)
} 
tertentu (Tjiptono, 2008). Tjiptono (2008) juga menjelaskan perusahaan yang dapat mendiferensiasikan dirinya secara efektif dari pada kompetitornya, dapat menjadi keberhasilan sebuah positioning dirinya di antara kompetitor. Tidaklah cukup hanya berfokus pada operasi internal dan tujuan jangka pendek namun juga harus menyeimbangkan peluang dan ancaman yang ada untuk menargetkan permintaan yang meningkat di pasar yang lebih luas (Shri, Gupta \& Agrawal, 2015). David (2004) menyatakan bahwa proses manajemen strategis terdiri dari tiga tahapan, yaitu memformulasikan strategi, mengimplementasi strategi, dan mengevaluasi strategi.

Untuk membuat strategi pemasaran, diperlukan evaluasi diri. Evaluasi diri yang dimaksud adalah perusahaan harus mengetahui kondisi internal dan eksternal. Kondisi internal dan eksternal dapat dilakukan dengan analisis SWOT. Untuk menentukan strategi mana yang dipilih diperlukan suatu metode yang mendukung. Oleh karena itu, dari permasalahan di atas, kami mencoba mengusulkan suatu strategi pemasaran dengan metode Quantitative Strategic Planning Matrix (QSPM). QSPM merupakan suatu metode untuk dapat membantu manajemen memilih strategi yang paling tepat untuk dilakukan.

Alasan digunakannya metode ini karena beberapa peneliti sebelumnya telah menggunakan metode ini pada industri yang serupa. Beberapa penelitian yang menggunakan QSPM contohnya yang dilakukan oleh Shri, Gupta \& Agrawal (2015) yang mengaplikasikan QSPM. pada industri kemasan yang dikelola oleh usaha kecil dan menengah di India. Shri, Gupta \& Agrawal (2015) mengidentifikasi isu strategis menggunakan QSPM dan berhasil memformulasikan strategi pemasaran pada industri tersebut. Ekasari (2018) memaparkan faktor yang sangat berpengaruh pada usaha air minum kemasan dengan menggunakan analisis SWOT dan QSPM. Strategi yang didapatkan diantaranya adalah mempertahankan harga untuk menguasai pasar, dilakukan promosi dengan mitra, dan penguatan manajemen dari perusahaan.

Dari uraian di atas, tujuan dari penelitian ini ada dua. Tujuan pertama adalah memformulasikan suatu strategi pemasaran pada pemasaran air minum dalam kemasan merek Baros dengan menggunakan SWOT. Tujuan kedua adalah memilih strategi pemasaran yang paling sesuai dengan air minum Baros. Usulan strategi yang tepat dari hasil studi ini diharapkan dapat meningkatkan penjualan dan melebarkan pasar.

\section{Metode Penelitian}

Gambar 1 merupakan tahap penelitian secara garis besar. Tahap pertama adalah tahap input yang mendefinisikan faktor eksternal dan faktor internal, juga mendefinisikan posisi persaingan perusahaan di antara kompetitor. Tahap kedua adalah tahap pencocokan, di mana pada tahap ini faktor eksternal, faktor internal dan posisi persaingan akan dicocokkan posisinya untuk mengetahui strategi yang akan diambil. Tahap terakhir adalah tahap keputusan, pada tahap ini akan dipilih strategi pemasaran yang dapat dilakukan oleh perusahaan.

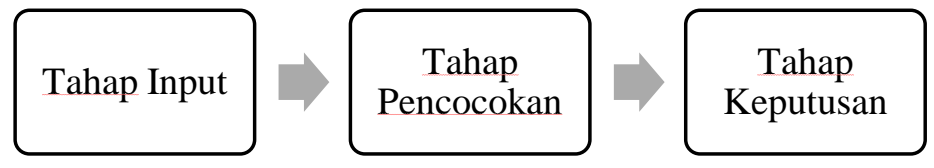

Gambar 1. Tahapan Penelitian

Pada tahap input, perusahaan perlu melakukan evaluasi terhadap faktor internal (Internal Factor Evaluation/IFE) dan evaluasi faktor eksternal (External Factor Evaluation/EFE) yang mempengaruhi perusahaan. Faktor internal mencakup kekuatan dan kelemahan utama dalam fungsi perusahaan (David, 2017). Faktor eksternal mencakup informasi ekonomi, sosial, budaya, demografi, lingkungan, politik, pemerintah, hukum, teknologi, dan persaingan (David, 2017). IFE dan EFE yang didapat kemudian diberi bobot. Jumlah bobot IFE adalah 1 begitu pula jumlah bobot EFE.

Selain IFE dan EFE, pada tahap input diperlukan juga Competitive Profile Matrix (CPM). CPM berguna untuk mengidentifikasi pesaing utama perusahaan serta kekuatan dan kelemahan pesaing terkait posisi strategis perusahaan (David, 2017). CPM terdiri dari faktor kesuksesan strategi bagi perusahaan yang dibandingkan dengan kompetitor. Setiap faktor kesuksesan diberi bobot dengan total jumlah bobot adalah 1. Kemudian diberi rating/peringkat. Peringkat pada perusahaan merupakan evaluasi diri perusahaan saat ini. Sedangkan peringkat pada kompetitor adalah cara pandang perusahaan dalam hal merespon strategi kompetitor. Bobot dikali dengan peringkat merupakan skor tertimbang. Total skor akan dipertimbangkan sebagai dasar membuat strategi. 
Tahap pencocokan dapat dilakukan dengan menggunakan analisis SWOT. Luaran analisis SWOT ini adalah strategi-strategi dari kombinasi SO, ST, WO, dan WT. Selanjutnya, perlu mengidentifikasi posisi perusahaan berada pada posisi tertentu dengan menggunakan matriks SPACE dan matriks Grand Strategy. Kedua alat tersebut dapat digunakan salah satunya, namun pada penelitian ini akan menggunakan keduanya agar lebih meyakinkan perusahaan dan dapat mengambil langkah yang tepat. Matriks SPACE melihat apakah strategi yang akan dirancang bersifat agresif, konservatif, defensif, atau kompetitif dilihat dari posisi keuangan (FS), posisi kompetitif (CP), posisi stabilitas (SP), dan posisi industri (IS). Selanjutnya dicocokkan dengan Matriks Grand Strategy yang melihat dari dua variabel evaluasi yaitu posisi bersaing dan pertumbuhan pasar.

Tahap terakhir adalah tahap keputusan menggunakan QSPM. Cara memilih strategi yang dipakai adalah dengan mempertimbangkan hasil dari tahap input dan tahap pencocokan. Strategi yang didapat pada tahap pencocokan kemudian diukur tingkat skor kemenarikan (Total Attractive Score/TAS) pada IFE dan EFE. Nilai TAS yang paling tinggi yang akan dipilih sebagai strategi bagi perusahaan. Pada penelitian ini, kami menggunakan Analytic Hierarchy Process (AHP) sebagai penguatan hasil yang diperoleh QSPM.

Untuk mendapatkan hasil yang diharapkan, penelitian ini membutuhkan responden yang paham posisi perusahaan. Oleh karena itu, responden pada penelitian ini adalah para manajer yang terdiri dari manajer pemasaran, manajer keuangan, manajer produksi, dan manajer logistik. Selain para manajer terdapat pula responden ahli pada bidang pemasaran.

\section{Hasil dan Pembahasan}

\subsection{Tahap Input}

Tahap ini merupakan tahap evaluasi faktor apa saja dari internal dan eksternal yang mempengaruhi perusahaan saat ini. Tabel 1 merupakan daftar faktor-faktor tersebut. Kekuatan dan kelemahan merupakan faktor internal. Sedangkan kesempatan dan ancaman merupakan faktor eksternal. Masing-masing faktor kemudian diberi bobot. Jumlah bobot faktor internal ( $\mathrm{S}$ dan $\mathrm{W}$ ) harus berjumlah 1. Begitu pula jumlah bobot faktor eksternal (O dan T). Bobot didapatkan dari hasil brainstorming para responden.

Tabel 1. Faktor internal dan eksternal perusahaan

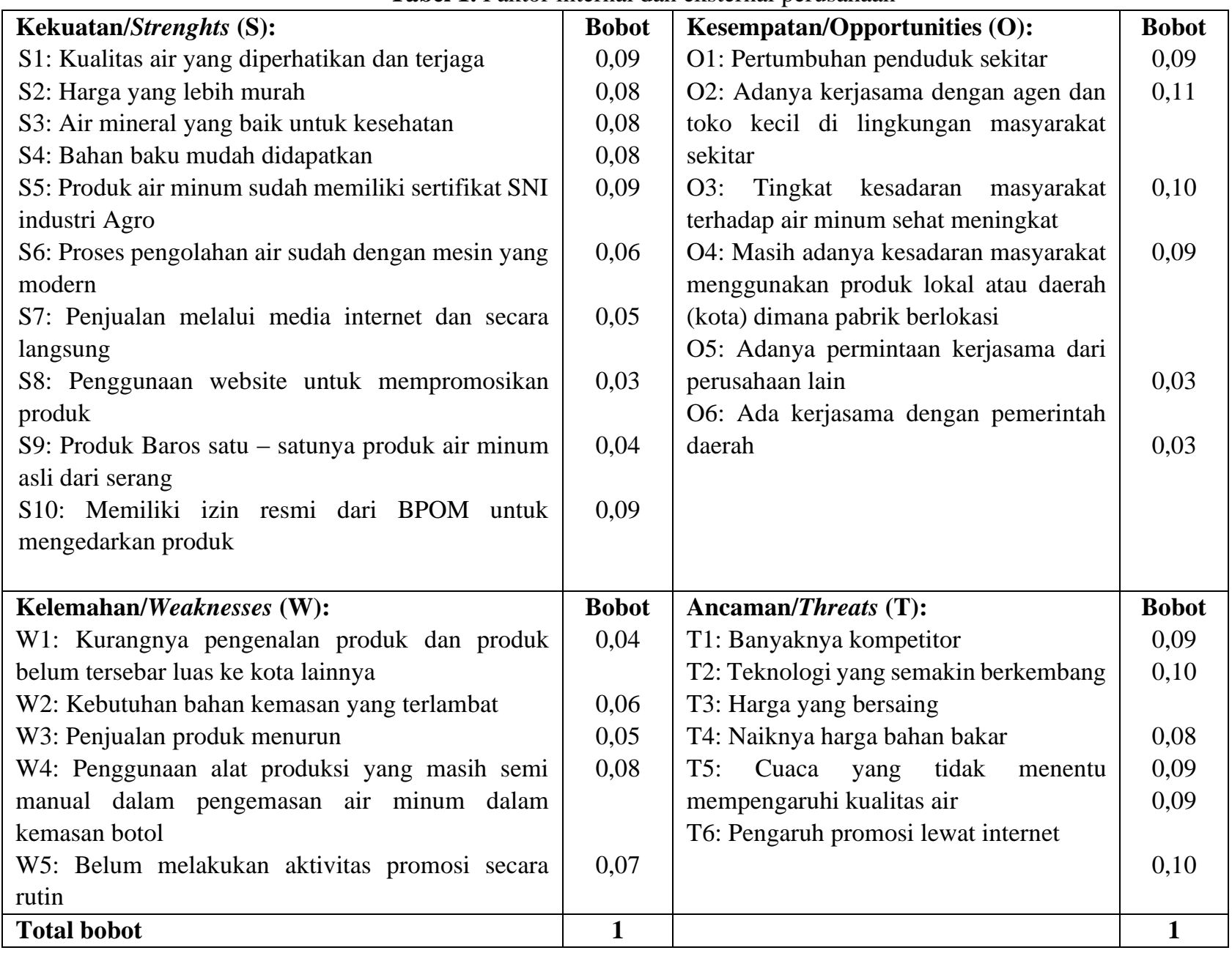


Tabel 2 adalah CPM yang merupakan perbandingkan posisi perusahaan saat ini dengan kompetitor yaitu perusahaan A dan perusahaaan B. Masing-masing faktor kesuksesan kemudian diberi bobot dengan total bobot adalah 1. Kemudian masing-masing faktor kesuksesan diberi peringkat untuk mendapatkan skor tertimbang. Faktor-faktor kesuksesan adalah faktor-faktor yang dipandang oleh pelanggan sebagai faktor yang berharga atau yang memberikan keuntungan signifikan bagi perusahaan dalam hal biaya dan faktor-faktor ini bervariasi dari satu industri ke industri lain atau bahkan dalam beberapa kasus dalam suatu industri, misalnya, dalam industri ritel, supermarket berbeda dari toko-toko (Johnson, Whittington \& Scholes, 2011). Perusahaan harus memperhatikan faktor-faktor kesuksesan kritis dan menggunakan faktor-faktor itu dengan sangat hati-hati untuk mengidentifikasi kesenjangan dalam penciptaan nilai dan memanfaatkan peluang untuk mengungguli saingan mereka dari aspek skenario kompetitif. Setelah perusahaan dapat mengidentifikasi faktor-faktor tersebut dan memasukkan informasi ini ke dalam pengembangan CPM, mereka dapat dengan mudah menemukan celah di pasar dalam hal penciptaan nilai dan bertindak cepat untuk menutupnya. Selain itu, manajer harus berhati-hati tentang satu-satunya kepercayaan pada aspek kuantitatif dan perlu mengawasi aspek kualitatif juga (Bhattacharjee \& Dey, 2015).

Faktor kesuksesan pada produk AMDK secara umum menjadi faktor pembanding antara produk Baros dan produk kompetitor. Dari data pada Tabel 2, terlihat skor total dari produk Baros adalah 2,80, skor kompetitor A adalah 2,4, dan skor kompetitor B adalah 3,40. Hal ini mengindikasikan produk Baros memiliki kekuatan bersaing di antara para kompetitor. Dari tabel tersebut terlihat produk Baros memiliki kekuatan tertinggi yaitu pada "kualitas produk" dengan skor 0,80 . Ini sebuah kekuatan yang harus dipertahankan dan dikembangkan oleh perusahaan.

Tabel 2. CPM

\begin{tabular}{cccccccc}
\hline \multirow{2}{*}{ Faktor Kesuksesan } & \multirow{2}{*}{ Bobot } & \multicolumn{2}{c}{ Baros } & \multicolumn{2}{c}{ Kompetitor A } & \multicolumn{2}{c}{ Kompetitor B } \\
\cline { 3 - 7 } & & Peringkat & Skor & Peringkat & Skor & Peringkat & Skor \\
\hline Iklan & 0,1 & 3 & 0,30 & 2 & 0,20 & 4 & 0,40 \\
Kualitas Produk & 0,2 & 4 & 0,80 & 2 & 0,40 & 3 & 0,60 \\
Harga Yang Bersaing & 0,15 & 3 & 0,45 & 2 & 0,30 & 4 & 0,60 \\
Manajemen & 0,15 & 2 & 0,30 & 4 & 0,60 & 3 & 0,45 \\
Posisi Keuangan & 0,1 & 2 & 0,20 & 4 & 0,40 & 3 & 0,30 \\
Loyalitas Konsumen & 0,15 & 3 & 0,45 & 2 & 0,30 & 4 & 0,60 \\
Ekspansi Global & 0,05 & 2 & 0,10 & 1 & 0,05 & 3 & 0,15 \\
Pangsa Pasar & 0,1 & 2 & 0,20 & 1 & 0,20 & 3 & 0,30 \\
\hline Total & $\mathbf{1 , 0 0}$ & & $\mathbf{2 , 8 0}$ & & $\mathbf{2 , 4 5}$ & & $\mathbf{3 , 4 0}$ \\
\hline
\end{tabular}

\subsection{Tahap Pencocokan}

Tahap pencocokan didefinisikan sebagai pencocokan yang dibuat organisasi antara sumber daya internal, kemampuan, dan kesempatan serta resiko yang diciptakan oleh faktor eksternalnya (David, 2017). Tahap pencocokan kerangka kerja formulasi strategi pada penelitian ini menggunakan tiga teknik yaitu Matriks SWOT, Matriks SPACE, dan Matriks Grand Strategy.

Matriks SWOT pada penelitian ini adalah alat pencocokan untuk mengetahui alternatif strategi yang baru dari hasil analisa EFE \& IFE dari produk Baros. SWOT membantu manajer mengembangkan empat tipe strategi, yaitu strategi Kekuatan-Kesempatan (SO), Kelemahan-Kesempatan (WO), Kekuatan-Ancaman (ST) dan Kelemahan-Ancaman (WT).

Dapat dilihat dari Tabel 3 bahwa telah terbentuk alternatif strategi yang dapat diterapkan oleh perusahaan. Strategi-strategi tersebut dapat dibagi menjadi dua yaitu, strategi taktis dan strategi pengembangan. Berikut ini adalah strategi taktis yang akan diolah kembali pada tahap pengambilan keputusan yaitu dengan QSPM, antara lain.

1. Meningkatkan dan mepertahankan kualitas air.

2. Meningkatkan akses penjualan melalui aplikasi media sosial dan online shop.

3. Mengadakan kerjasama dengan pemerintah daerah dan perusahaan lain.

4. Mempertahankan harga produk dan kualitas air.

5. Mengembangkan mesin produksi. 
Tabel 3. Hasil Analisis SWOT

\begin{tabular}{|c|c|c|}
\hline & Kekuatan - S & Kelemahan - W \\
\hline & $\mathrm{S} 1$ & W1 \\
\hline & $\mathrm{S} 2$ & W2 \\
\hline & $\mathrm{S} 3$ & W3 \\
\hline & $\mathrm{S} 4$ & W4 \\
\hline & $\mathrm{S} 10$ & W5 \\
\hline Kesempatan & \multirow{8}{*}{$\begin{array}{l}\text { Strategi - SO } \\
\text { 1. Meningkatkan dan mepertahankan } \\
\text { kualitas air ( } \mathrm{S} 1, \mathrm{~S} 3, \mathrm{~S} 5, \mathrm{~S} 6, \mathrm{~S} 10, \mathrm{O} 3) \\
\text { 2.Meningkatkan akses penjualan aplikasi } \\
\text { media sosial online shop (S7,S8,O1,O2,O3) } \\
\text { 3.Mengadakan kerjasama dengan } \\
\text { pemerintah daerah dan perusahaan lain } \\
(\mathrm{S} 5, \mathrm{~S} 10, \mathrm{~S} 9, \mathrm{O} 5, \mathrm{O} 6)\end{array}$} & \multirow{8}{*}{$\begin{array}{l}\text { Strategi - WO } \\
\text { 1.Melakukan pengenalan produk } \\
\text { secara } \\
\quad \text { berkala ke masyarakat } \\
(\mathrm{W} 1, \mathrm{~W} 5, \mathrm{O} 1, \mathrm{O} 3, \mathrm{O} 4)\end{array}$} \\
\hline$-\mathrm{O}$ & & \\
\hline $\mathrm{O} 1$ & & \\
\hline $\mathrm{O} 2$ & & \\
\hline $\mathrm{O} 3$ & & \\
\hline $\mathrm{O} 4$ & & \\
\hline O5 & & \\
\hline O6 & & \\
\hline Ancaman - T & \multirow{7}{*}{$\begin{array}{l}\text { Strategi - ST } \\
\text { 1.Mempertahankan harga produk dan } \\
\text { kualitas air (S1,S2,S3,S5,S6,S10, T1,T2) } \\
\text { 2.Meningkatkan pengetahuan akan } \\
\text { teknologi yang baru. (S6,T2) }\end{array}$} & Strategi - WT \\
\hline $\mathrm{T} 1$ & & 1.Mengembangkan mesin produksi \\
\hline $\mathrm{T} 2$ & & $(\mathrm{~W} 4, \mathrm{~T} 2)$ \\
\hline T3 & & 2.Melakukan pengenalan produk \\
\hline $\mathrm{T} 4$ & & melalui \\
\hline T5 & & media internet atau media sosial \\
\hline T6 & & $(\mathrm{W} 1, \mathrm{~W} 5, \mathrm{~T} 1, \mathrm{~T} 6)$ \\
\hline
\end{tabular}

Selanjutnya pencocokan dengan matriks SPACE untuk mengetahui apakah strategi yang digunakan akan agresif, konservatif, defensif, atau kompetitif yang sesuai dengan produk Baros. Perpotongan Matriks SPACE merepresentasikan dua dimensi internal [posisi keuangan (financial position - FP) dan posisi kompetitif (competitive position - CP)] serta dua dimensi eksternal [posisi stabilitas (stability position - PS) dan posisi industri (indsutry position - IP)]. Faktor - faktor ini adalah penentu yang paling penting dalam posisi strategik organisasi secara keseluruhan (David, 2017). Hasil matriks SPACE dapat dilihat pada Tabel 4 dan Gambar 1.

Tabel 4. Hasil Matriks SPACE

\begin{tabular}{lclc}
\hline \multicolumn{1}{c}{ Analisis Internal } & \multicolumn{2}{c}{ Analisis Eksternal } \\
\hline \multicolumn{1}{c}{ Posisi Keuangan (FP) } & Peringkat & \multicolumn{1}{c}{ Posisi Stabil (SP) } & Peringkat \\
\hline Tingkat Kembalian Investasi & 4 & Pengaruh Inflasi \\
Modal Kerja & 5 & $\begin{array}{l}\text { Pengaruh Perkembangan } \\
\text { Teknologi }\end{array}$ & -4 \\
Arus Kas & 4 & Elastisitas Permintaan & -2 \\
Pendapatan & 5 & Tekanan Kompetitif & -3 \\
\hline Rata - rata FP & $\mathbf{4 , 5}$ & Rata- rata SP & -4 \\
\hline \multicolumn{1}{c}{ Posisi Kompetitif $(\mathbf{C P})$} & \multicolumn{1}{c}{ Posisi Industri (IP) } \\
Kualitas Produk & -2 & Potensi Pertumbuhan & $\mathbf{- 3 , 0}$ \\
Loyalitas Konsumen & -2 & Stabilitas Keuangan & 6 \\
Pembagian Pasar & -3 & Kemudahan Masuk Pasar & 4 \\
Pengendalian Distributor & -3 & Pemanfaaatan Sumberdaya & 5 \\
& & Potensi Laba & 6 \\
\hline Rata - rata CP & $\mathbf{- 2 , 4}$ & Rata - rata IP & 4 \\
\hline FP + SP = 4,5 + (-3,0) = 1,0 perpotongan Y & \\
IP + CP = 5,1 + (-2,4) = 3,7 perpotongan X & \\
Kesimpulan : poin vektor berada dalam kuadran agresif & $\mathbf{5 , 1}$ \\
\hline
\end{tabular}

Diketahui dari Tabel 4 bahwa posisi strategi produk Baros berada pada posisi kuadran I yaitu agresif. Yang berarti perusahaan dalam posisi yang sangat baik dalam menggunakan kekuatan internalnya untuk mendapat keuntungan dari kesempatan eksternal, dapat menangani kelemahan internal dan dapat menghindari ancaman eksternal (Harahap, 2018). Jadi strategi yang cocok strategi agresif. Strategi agresif terdiri dari penetrasi pasar, pengembangan pasar, pengembangan produk, integrasi kebelakang, integrasi ke depan, integrasi horizontal atau disverifikasi merupakan strategi yang layak, tergantung pada kondisi khusus yang dihadapi oleh perusahaan. 


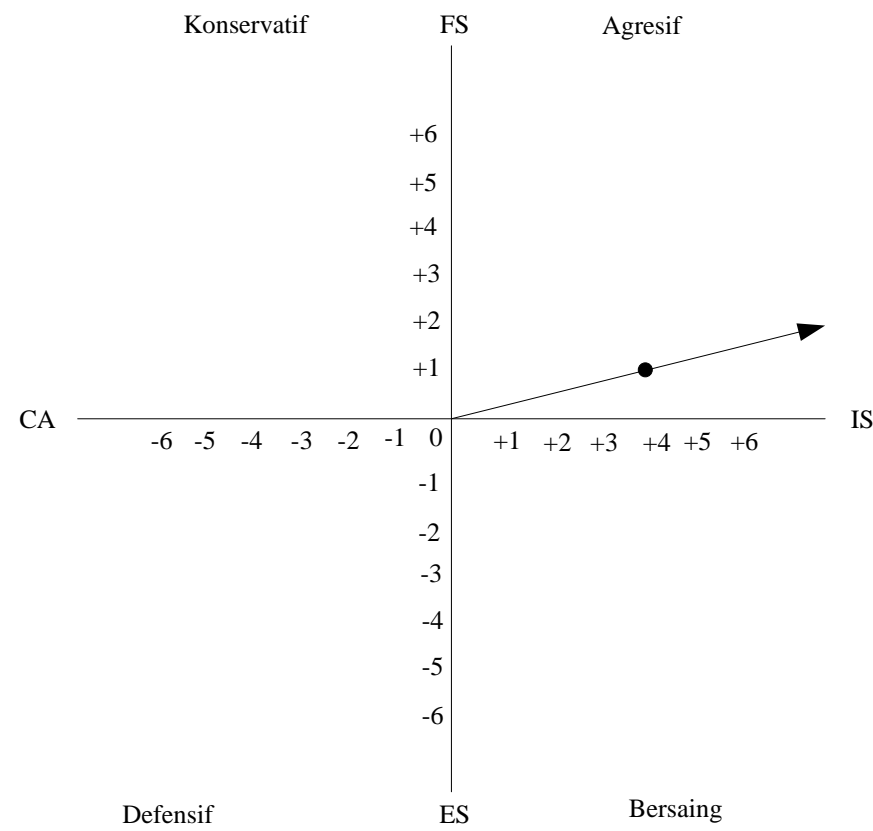

Gambar 1. Matriks Space produk Baros

Teknik pencocokan kedua adalah matriks Grand Strategy. Peran grand strategy adalah untuk mengoordinasikan dan mengarahkan semua sumber daya perusahaan ke arah pencapaian tujuan dan sasaran serta visinya. Ini adalah pernyataan tindakan strategis. Grand strategy menyatakan cara yang akan digunakan untuk mencapai tujuan jangka panjang. Contoh strategi besar bisnis meliputi; strategi konsentrasi, strategi pengembangan pasar, strategi ekspansi atau pertumbuhan, strategi pengembangan produk, strategi inovasi, strategi integrasi, divestasi, strategi likuidasi, strategi stabilitas dan strategi penghematan atau divestasi mana saja yang bersifat menyeluruh (Kavale, Mugambi \& Namusonge, 2016). Untuk menentukan posisi matriks dibutuhkan skor ini dilihat dari matriks EFE dan IFE produk Baros pada tahap input. Berikut ini adalah matriks Grand Strategy dapat dilihat pada Tabel 5 dan Gambar 2. Dari Tabel 5 dapat diketahui bahwa posisi strategi perusahaan memiliki nilai eksternal 3,0928 dan nilai internal 2,8956. Dengan nilai yang hampir seimbang dan memiliki nilai positif. Ini membuktikan bahwa produk Baros terdapat pada kuadran I yang berarti perusahaan ada pada posisi strategis yang sangat baik. Konsentrasi perusahaan berkelanjutan pada penetrasi pasar, pengembangan pasar, dan pengembangan produk.

Tabel 5. Skor IFE dan EFE

\begin{tabular}{|c|c|c|c|c|c|c|c|}
\hline $\begin{array}{c}\text { Kekuatan/ (S): } \\
\text { S1 } \\
\text { S2 } \\
\text { S3 } \\
\text { S4 } \\
\text { S5 } \\
\text { S6 } \\
\text { S7 } \\
\text { S8 } \\
\text { S9 } \\
\text { S10 }\end{array}$ & $\begin{array}{c}\text { Bobot } \\
0,09 \\
0,08 \\
0,08 \\
0,08 \\
0,09 \\
0,06 \\
0,05 \\
0,03 \\
0,04 \\
0,09\end{array}$ & $\begin{array}{c}\text { Peringkat } \\
4 \\
3 \\
3 \\
3 \\
4 \\
2 \\
2 \\
1 \\
2 \\
4\end{array}$ & $\begin{array}{c}\text { Skor } \\
0,3572 \\
0,2688 \\
0,2856 \\
0,2624 \\
0,3168 \\
0,1392 \\
0,1188 \\
0,0476 \\
0,0684 \\
0,3384\end{array}$ & $\begin{array}{c}\text { Kesempatan }(\mathrm{O}): \\
\text { O1 } \\
\mathrm{O} 2 \\
\mathrm{O} 3 \\
\mathrm{O} 4 \\
\mathrm{O} 5 \\
\text { O6 }\end{array}$ & $\begin{array}{c}\text { Bobot } \\
0,09 \\
0,11 \\
0,10 \\
0,09 \\
0,03 \\
0,03\end{array}$ & $\begin{array}{c}\text { Peringkat } \\
3 \\
4 \\
4 \\
3 \\
1 \\
1\end{array}$ & $\begin{array}{c}\text { Skor } \\
0,264 \\
0,3816 \\
0,3744 \\
0,264 \\
0,0384 \\
0,036\end{array}$ \\
\hline $\begin{array}{c}\text { Kelemahan }(\mathrm{W}): \\
\text { W1 } \\
\text { W2 } \\
\text { W3 } \\
\text { W4 } \\
\text { W5 }\end{array}$ & $\begin{array}{l}0,04 \\
0,06 \\
0,05 \\
0,08 \\
0,07\end{array}$ & $\begin{array}{l}2 \\
2 \\
2 \\
3 \\
3\end{array}$ & $\begin{array}{l}0,0576 \\
0,1392 \\
0,1056 \\
0,2184 \\
0,1716\end{array}$ & $\begin{array}{c}\text { Ancaman }(\mathrm{T}): \\
\text { T1 } \\
\text { T2 } \\
\text { T3 } \\
\text { T4 } \\
\text { T5 } \\
\text { T6 }\end{array}$ & $\begin{array}{l}0,09 \\
0,10 \\
0,08 \\
0,09 \\
0,09 \\
0,10\end{array}$ & $\begin{array}{l}3 \\
3 \\
3 \\
3 \\
3 \\
4\end{array}$ & $\begin{array}{c}0,276 \\
0,3332 \\
0,2028 \\
0,3008 \\
0,276 \\
0,3456\end{array}$ \\
\hline Total & & & 2,8956 & & & & 3,0928 \\
\hline
\end{tabular}




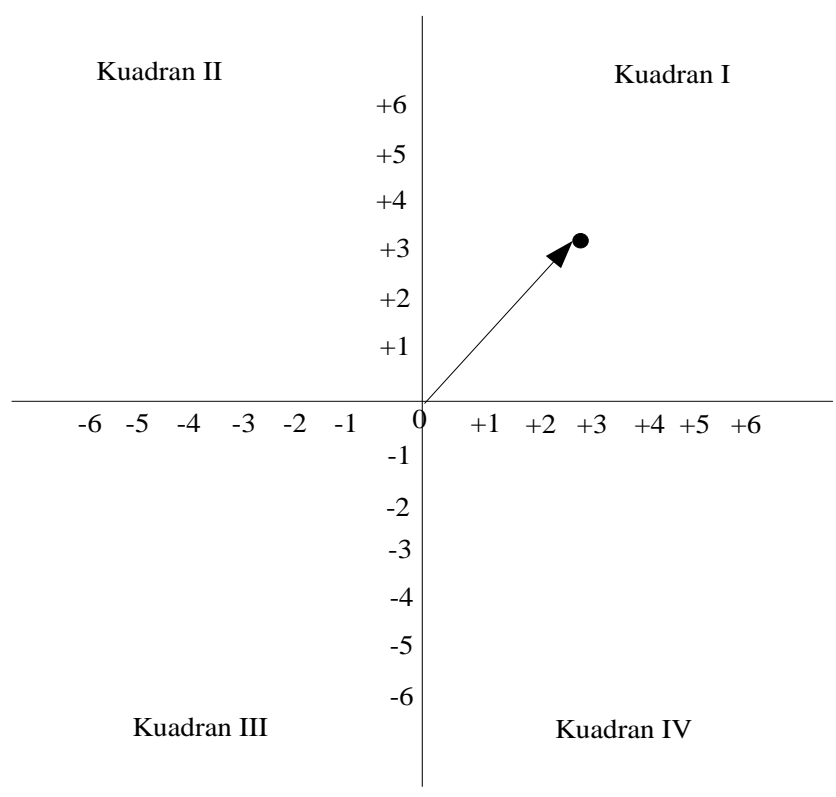

Gambar 2. Hasil Grand Strategy produk Baros

\subsection{Tahap Keputusan}

Pada tahap ini dilakukan pengambilan keputusan yang melibatkan para manajer untuk menjadi pengambil keputusan. Teknik yang digunakan adalah QSPM. Tabel 6 memperlihatkan hasil dari QSPM. Nilai TAS masing-masing strategi didapatkan dari perkalian antara bobot dan skor kemenarikan. Skor adalah peringkat yang diberikan oleh para manajer untuk menilai dampak faktor IFE dan EFE pada strategi yang diamati. Dari 5 strategi taktis yang didapatkan, masing-masing ditentukan nilai TAS. Tabel 6 merupakan contoh perhitungan TAS pada strategi 1 yaitu "meningkatkan dan mempertahankan kualitas air". Tabel 7 merupakan hasil perhitungan TAS untuk lima strategi taktis.

Tabel 6. Contoh perhitungan TAS pada Strategi 1

\begin{tabular}{cccc}
\hline \multicolumn{5}{c}{ Strategi 1: Meningkatakan dan mempertahankan kualitas air } \\
\hline IFE EFE & Bobot & Skor & TAS \\
\hline O1 & 0,09 & 3 & 0,29 \\
O2 & 0,11 & 3 & 0,35 \\
O3 & 0,1 & 4 & 0,35 \\
O4 & 0,09 & 3 & 0,26 \\
O5 & 0,03 & 3 & 0,09 \\
O6 & 0,03 & 3 & 0,10 \\
T1 & 0,09 & 3 & 0,27 \\
T2 & 0,1 & 3 & 0,30 \\
T3 & 0,08 & 3 & 0,24 \\
T4 & 0,09 & 3 & 0,23 \\
T5 & 0,09 & 2 & 0,17 \\
T6 & 0,1 & 4 & 0,37 \\
S1 & 0,09 & 4 & 0,33 \\
S2 & 0,08 & 3 & 0,27 \\
S3 & 0,08 & 4 & 0,28 \\
S4 & 0,08 & 3 & 0,20 \\
S5 & 0,09 & 4 & 0,35 \\
S6 & 0,06 & 3 & 0,19 \\
S7 & 0,05 & 4 & 0,19 \\
S8 & 0,03 & 4 & 0,12 \\
S9 & 0,04 & 3 & 0,11 \\
S10 & 0,09 & 4 & 0,35 \\
\hline & & &
\end{tabular}


Tabel 6. Contoh perhitungan TAS pada Strategi 1 (lanjutan)

\begin{tabular}{cccc}
\multicolumn{5}{c}{ Strategi 1: Meningkatakan dan mempertahankan kualitas air } \\
\hline IFE EFE & Bobot & Skor & TAS \\
\hline W1 & 0,04 & 3 & 0,11 \\
W2 & 0,06 & 2 & 0,14 \\
W3 & 0,05 & 3 & 0,13 \\
W4 & 0,08 & 2 & 0,19 \\
W5 & 0,07 & 3 & 0,22 \\
& & & $\mathbf{6 , 1 6}$
\end{tabular}

Tabel 7. Nilai TAS masing-masing strategi

\begin{tabular}{clcc}
\hline No & \multicolumn{1}{c}{ Strategi Alternatif } & Nilai TAS & Peringkat \\
\hline 1 & Meningkatkan dan mepertahankan kualitas air. & 6,16 & 2 \\
2 & $\begin{array}{l}\text { Meningkatkan akses penjualan melalui aplikasi media } \\
\text { Sosial dan online shop. }\end{array}$ & 6,26 & 1 \\
3 & $\begin{array}{l}\text { Mengadakan kerjasama dengan pemerintah daerah dan } \\
\text { perusahaan lain. }\end{array}$ & 5,75 & 5 \\
4 & Mempertahankan harga produk dan kualitas air. & 5,99 & 3 \\
5 & Mengembangkan mesin produksi. & 5,77 & 4 \\
\hline
\end{tabular}

Tabel 7 memperlihatkan nilai TAS yang paling besar ada pada strategi 2 yaitu sebesar 6,26. Selanjutnya sebagai penguatan, kami menggunakan AHP. AHP adalah pendekatan untuk memfasilitasi pengambilan keputusan dengan mengatur persepsi, perasaan, penilaian dan memori ke dalam struktur hierarki multi-level yang menunjukkan kekuatan yang mempengaruhi keputusan (Saaty, 1994). Para manajer masih terlibat untuk menentukan prioritas yang ditunjukkan dengan bobot. Gambar 3 merupakan hirarki dari strategi taktis. Kriteria dibagi menjadi biaya, SDM, dan teknologi. Tabel 8, Tabel 9, dan Tabel 10 menunjukkan bobot priotitas pada masing-masing kriteria.

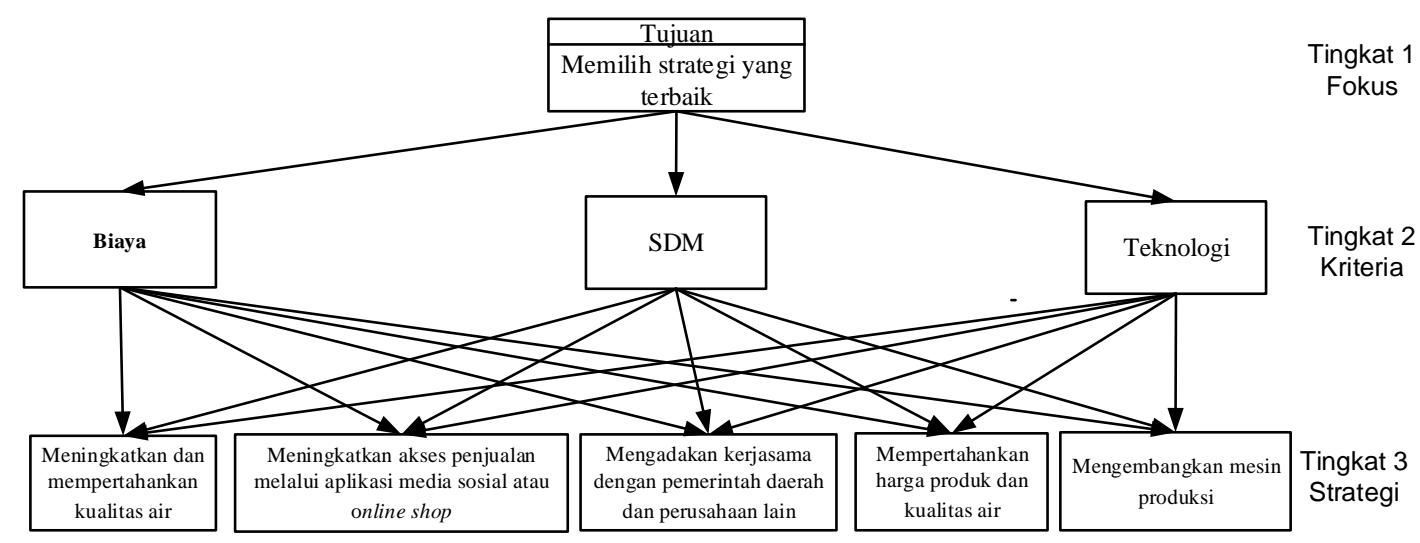

Gambar 3. Hierarki Pemilihan Strategi

Tabel 8. Bobot berdasarkan kriteria biaya

\begin{tabular}{ccccccccc}
\hline Strategi & Strategi 1 & Strategi 2 & Strategi 3 & Strategi 4 & Strategi 5 & total & $\begin{array}{c}\text { bobot } \\
\text { prioritas }\end{array}$ & Peringkat \\
\hline Strategi 1 & 0,09 & 0,09 & 0,07 & 0,07 & 0,15 & 0,47 & 0,09 & 4 \\
Strategi 2 & 0,53 & 0,55 & 0,63 & 0,52 & 0,41 & 2,63 & 0,53 & 1 \\
Strategi 3 & 0,20 & 0,14 & 0,17 & 0,26 & 0,23 & 1,00 & 0,20 & 2 \\
Strategi 4 & 0,13 & 0,10 & 0,06 & 0,10 & 0,13 & 0,52 & 0,10 & 3 \\
Strategi 5 & 0,05 & 0,12 & 0,06 & 0,06 & 0,09 & 0,38 & 0,08 & 5 \\
Total & & & & & & & & 1,00 \\
\hline
\end{tabular}


Tabel 9. Bobot berdasarkan kriteria SDM

\begin{tabular}{ccccccccc}
\hline Strategi & Strategi 1 & Strategi 2 & Strategi 3 & Strategi 4 & Strategi 5 & total & $\begin{array}{c}\text { bobot } \\
\text { prioritas }\end{array}$ & Peringkat \\
\hline Strategi 1 & 0,12 & 0,15 & 0,08 & 0,09 & 0,21 & 0,65 & 0,13 & 3 \\
Strategi 2 & 0,38 & 0,45 & 0,58 & 0,39 & 0,33 & 2,13 & 0,43 & 1 \\
Strategi 3 & 0,29 & 0,15 & 0,19 & 0,30 & 0,27 & 1,21 & 0,24 & 2 \\
Strategi 4 & 0,15 & 0,13 & 0,07 & 0,11 & 0,10 & 0,56 & 0,11 & 4 \\
Strategi 5 & 0,05 & 0,13 & 0,07 & 0,11 & 0,09 & 0,45 & 0,09 & 5 \\
Total & & & & & & & 1,00 & \\
\hline
\end{tabular}

Tabel 10. Bobot kriteria teknologi

\begin{tabular}{ccccccccc}
\hline Strategi & Strategi 1 & Strategi 2 & Strategi 3 & Strategi 4 & Strategi 5 & Total & $\begin{array}{c}\text { bobot } \\
\text { prioritas }\end{array}$ & Peringkat \\
\hline Strategi 1 & 0,12 & 0,13 & 0,12 & 0,07 & 0,20 & 0,64 & 0,13 & 3 \\
Strategi 2 & 0,40 & 0,41 & 0,48 & 0,36 & 0,27 & 1,92 & 0,38 & 1 \\
Strategi 3 & 0,25 & 0,21 & 0,25 & 0,42 & 0,27 & 1,41 & 0,28 & 2 \\
Strategi 4 & 0,16 & 0,11 & 0,06 & 0,10 & 0,16 & 0,59 & 0,12 & 4 \\
Strategi 5 & 0,06 & 0,14 & 0,08 & 0,05 & 0,09 & 0,43 & 0,09 & 5 \\
Total & & & & & & 5,00 & 1,00 & \\
\hline
\end{tabular}

Tabel 8, Tabel 9, dan Tabel 10 terlihat bobot yang paling besar pada setiap kriteria ada pada strategi kedua. Maka dapat disimpulkan bahwa strategi kedua sebagai strategi yang dipilih untuk meningkatkan daya saing produk Baros. Strategi kedua adalah meningkatkan akses penjualan melalui aplikasi media sosial dan online shop. Strategi ini cocok diimplementasikan mengingat berkembangnya era digital. Suatu merek dapat berkampanye lewat sosial media untuk meningkatkan brand awarness. Dan dapat mudah diaplikasikan terutama untuk masyarakat di Serang.

\section{Simpulan}

Penentuan strategi pemasaran yang tepat diperlukan bagi suatu perusahaan agar dapat bersaing dengan kompetitor di pasar yang sama. Beberapa tahap dalam menentukan strategi ini dirasa cukup terstruktur dan komprehensif. Data-data seperti faktor eksternal sebagai kesempatan dan ancaman dan faktor internal sebagai kekuatan dan kelemahan dari diri perusahaan sebagai bahan evaluasi diri sendiri. Dari tahapan menentukan strategi yang efektif bagi produk air minum dalam kemasan merek Baros didapatkan lima strategi taktis seperti yang telah diuraikan di atas. Dari kelima strategi tersebut didapatkan strategi 2 yang terpilih yaitu meningkatkan akses penjualan melalui aplikasi media sosial dan online shop.

\section{Daftar Pustaka}

Bhattacharjee, D. \& Dey, M. (2015). Competitive Profile Matrix: A Theoretical Review. ABAC Journal, Vol. 35 No. 2, hal 61-70.

Ekasari, E. N. (2018). Analisis Strategi Pemasaran Air Minum Dalam Kemasan Dengan Quantitative Strategic Planning Matrix (QSPM) [online]. http://eprints.ums.ac.id/65963/ (diakses pada 31 Januari 2019).

David, F . R. (2004). Manjemen Strategis : Konsep. Edisi 7, Jakarta: PT INDEKS.

David, F. R. (2017). Manajemen Strategik : Suatu Pendekatan Keunggulan Bersaing - Konsep. Edisi 15, Jakarta: Salemba Empat.

Harahap, U. N., Eddy, \& Afriyanto, A. (2018). Perumusan Strategi Pemasaran Menggunakan Metode Quantitative Strategy Planning Matrix (QSPM) Sebagai Upaya Peningkatan Penjualan Kernel Oil di PT Anugerah Sawit Dio. Juriti Prima, Vol. 2 No. 1, hal 11-21.

Johnson, G., Whittington,R., \& Scholes, K. (2011). Exploring strategies: Text and cases. Harlow: Financial time Prentice Hall.

Kavale, S., Mugambi, F., \& Namusoge, G. (2016). The Effects Of Grand Strategy On Corporate Growth In Selected Microfinance Institutions In Kenya. IJRDO - Journal of Business Management, Vol. 2 Issue 6, hal 1-16.

Rini, A.S. (2018). Permintaan Kuat, Air Minum Kemasan Optimis Capai Target [online] https://surabaya.bisnis.com/read/20181012/257/848691/permintaan-kuat-air-minum-kemasan-optimiscapai-target (diakses 4 Februari 2019). 
Saaty, T. L. (1993). Pengambilan Keputusan Bagi Para Pemimpin Dalam Ir. Kirti Peniwati, MBA. Edisi 2. Jakarta: PT. Gramedia.

Saaty, T. L. (1994). Fundamental Of Decision Making And Priority Theory With The Analytic Hierarchy Process. Pittsburgh USA : RWS Publications.

Shri, C., Gupta, M., \& Agraawal, A. Strategy Formulation for Performance Improvement of Indian Corrugated Industry: An Application of SWOT Analysis and QSPM Matrix. Journal of Applied Packaging Research, Vol 7 No 3, hal 60-75.

Tjiptono, F. (2008). Strategi Pemasaran Edisi 3. Yogyakarta: Andi.

Zimmerer T.W., Scarborough, N.M., \& Wilson, D. (2008). Essentials of entrepreneurship and small business management (5th ed). NJ: Prentice Hall. 